\section{ECONOMICS}

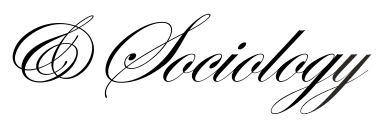

Vasilyeva, T., Kuzmenko, O., Kuryłowicz, M., \& Letunovska, N. (2021). Neural network modeling of the economic and social development trajectory transformation due to quarantine restrictions during COVID-19. Economics and Sociology, 14(2), 313-330. doi:10.14254/2071-789X.2021/14-2/17

\title{
NEURAL NETWORK MODELING OF THE ECONOMIC AND SOCIAL DEVELOPMENT TRAJECTORY TRANSFORMATION DUE TO QUARANTINE RESTRICTIONS DURING COVID-19
}

Tetyana Vasilyeva

Department of Finance and

Entrepreneurship,

Sumy State University,

Ukraine

tavasilyeva@fem.sumdu.edu.ua

ORCID 0000-0003-0635-7978

Olha Kuzmenko

Department of Economic

Cybernetics,

Sumy State University,

Ukraine

o.k.uzmenko@uabs.sumdu.edu.ua

ORCID 0000-0001-8520-2266

Mariusz Kuryłowicz

Institute of Security Sciences, Higher

School of Criminology and

Penitentiary Science in Warsaw,

Warsaw, Poland

mariusz.kurylowicz@,wskip.edu.pl

ORCID 0000-0001-8995-6516

Nataliia Letunovska

Department of Marketing,

Sumy State University,

Ukraine

n.letunovska@,kmm.sumdu.edu.ua

ORCID 0000-0001-8207-9178

Received: April, 2020

1st Revision: March, 2021

Accepted: June, 2021
ABSTRACT. The article uses neural networks to model the effects of quarantine restrictions on the most important indicators of the country's socio-economic development. The authors selected the most relevant indicators and formed a specific sequence of its calculation to study the direction of transforming the trajectory of socio-economic development of a particular country due to quarantine restrictions. They used a multilayer MLP perceptron and networks based on radial basis functions. They chose BFGS and RBFT algorithms in neural network modeling. Collinearity study was the basis for data mining in terms of key factors of change. The author's approach is unique due to an iterative procedure of numerical optimization and quasi-Newton methods ("self-learning" and step-by-step "improvement" of neural networks). The model projected gross domestic product and the number of unemployed in the country affected by the COVID-19 pandemic over the three years.

DOI: $10.14254 / 2071-$

789X.2021/14-2/17 
JEL Classification: C45, O18, R13

\begin{abstract}
Keywords: impact of COVID-19, forecast of quarantine measures impact, socio-economic development of Ukraine, economicmathematical model, neural network.
\end{abstract}

\section{Introduction}

Since the first cases of the SARS-CoV-2 virus, the COVID-19 pandemic has caused a number of negative effects on society and the economic development of entire regions. There is an urgent need to analyze the impact of COVID-19 as a threat to health and sustainable development on the current vector of world society transformations with a clear answer to the question of what this impact will be in retrospect on a national and regional scale. The trajectory of the strength and direction of the impact made by coronavirus and quarantine measures on socio-economic development can provide opportunities to develop accurate and sound forecasts of the consequences of the events 2020 for the coming years' global economy.

The pandemic lockdown affects almost all areas on a national scale - public health (direct effect), economic, social, environmental development (indirect effect). The downside of lockdown includes the collisions in the economic, social, and ecological spheres (Smiianov et al., 2020b). Experts in various fields of knowledge confirm that this global pandemic is an element of tension, primarily for global supply chains, causing catastrophic negative consequences due to the world economy's interconnectedness (Cek \& Eyupoglu, 2020). Didenko et al. (2020), through bibliographic analysis, prove that migration parameters as a key economic indicator, environment, and security often meet each other. When writing the article, the coronavirus has killed nearly 2 million people worldwide (Worldometers, 2021), created problems for many people, and caused trillion economic losses. Most countries worldwide take strict measures, particularly national blockades and border closures, to contain the growing number of COVID-19 cases and limit the transmission of the dangerous virus. It is essential to provide calculations and realistic models to answer what changes are appropriate to implement in the countries to reduce the negative impact of the pandemic on most aspects of public life.

The purpose of this study is to forecast the impact of quarantine measures aimed at preventing the spread of coronavirus, at changing trends in social and economic development in different scenarios of future epidemiological threats. It considers the most important indicators of socio-economic development with forecasts for three years. The authors apply an approach that is fundamentally different from those already existing in the scientific literature, using an iterative procedure of numerical optimization and quasi-Newton methods that provide the "self-learning" and step-by-step "improvement" of neural networks. The approach considers possible dynamic changes of input parameters and parallel processing of information by many neurons.

\section{Literature review}

The articles of scientists from different countries deal with the impact of various crises, mainly of economic nature, and its quantitative and parametric analysis, in their works. The comparison of socio-economic development of individual regions, which are differently susceptible to such crises and form different resulting actions on the directed influence, is of particular importance (Bazyliuk et al., 2019; Kryshtanovych et al., 2020; Haller, 2020; Mikhaylova et al., 2019; Afanasyev et al., 2020; Dinu et al., 2020; Iacobuta et al., 2019; Semenenko et al., 2019; Harust et al., 2019; Vysochyna et al., 2020; Mikhnevych et al., 2020; 
Deyneka et al., 2019; Medani, 2020; Balas and Kaya, 2019; Yelnikova and Miskiewicz, 2020; Dave, 2019; Marcel, 2019; Hashim et al., 2018; Kuzmenko et al., 2020; Djalilov et al., 2015). Attention is paid to the calculation of these impact limits in different activities (Mach, 2019; Moyo, 2020; Sawangchai, 2020; Przytuła et al., 2020; Raychev et al., 2020; Kowo et al., 2020; Jafarzadeh and He, 2019; Greco, 2018; Yiu et al., 2020; Dutta et al., 2020; Lopez and Alcaide, 2020; Kouassi, 2018) or in different countries and in the world as a whole (Sułkowski, 2020; Nagy and Kiss, 2018; Zolkover and Renkas, 2020). In particular, KucCzarnecka (2020) examines specific aspects of the COVID-19 pandemic impact through the example of Poland, identifying particularly vulnerable areas due to infrastructural deficiencies. Censolo and Morelli (2020) view COVID-19 as a factor of unexpected and unpredictable social stability changes. According to them, it is urgent to consolidate the government and society's actions to achieve pre-pandemic stability. They separately study the incubator of conflict and repression caused by a pandemic. Leach et al. (2021) justify the need to forecast future uncertain shocks, which include pandemics. Such events form a challenge to the structural conditions in some countries, their social relations and economic order (Rui et al., 2019). Long-term transformations in the socio-economic sphere aim to solve fundamental issues of stimulating reliable and innovative alternatives to post-pandemic economic recovery. Vo (2020) views the COVID-19 pandemic from two perspectives - as an economic crisis and a crisis in the public health system. The author argues that it is essential to study changes in the agricultural market and the energy market during the crisis. The research in this article is based on the example of the United States. There are interesting practical studies, mainly (Cepel et al., 2020), that analyze the COVID-19 crisis impact on the entrepreneurs' attitude to risk. The study is conducted on the example of the small and medium enterprises segment in the Czech Republic and Slovakia, outlining the pandemic impact on these European countries' business sector.

Mofijur et al. (2021) present a comprehensive study regarding the COVID-19 impact on public life, including the economy, social sphere, environment and energy sector. It is essential to comprehensively analyze governments' measures to prevent the epidemic and their effectiveness in achieving a sustainable socio-economic environment. Smiianov V.A. et al. (2020a) thoroughly investigate the labor market analysis methods in a pandemic, forming their approach with a system of calculated parameters-indicators of the market situation. Many authors offer their economic and mathematical models to forecast the COVID-19 dynamics in the world, which differ in approach to construction, the accuracy of presented results, validity, etc. (Kufel, 2020), as well as valuable results of marketing research on mechanisms to improve the medical service quality, which is an essential aspect in preventing the epidemics spread (Smiianov et al., 2017). The scientists' achievements in the sustainable development of territorial units are relevant in current conditions because there is an essential strategic task of society to balance the development of different regions to overcome the crisis is (Petrushenko et al., 2017, Petrushenko et al., 2020, Stukalo et al., 2020). The appropriateness of applying modern mathematical methods to forecast economic phenomena is substantiated in many scientific studies (Teletov et al., 2019; Rosokhata et al., 2020; Vasilyeva et al., 2020; Yarovenko et al., 2021). Such scientists as Hruschka (1993), Luxhoy et al. (1996), Morozov et al. (2020), Vrbka (2020) are working to develop certain specific issues regarding the neural networks in the socio-economic sphere to define the drivers for further development of individual economic entities and countries as a whole.

\section{Methodology}

The most relevant indicators and calculations are used (Sumiyana, 2020; Malyarets et al., 2019; Vasilyeva et al., 2019) to study the economic and social development trajectory 
transformation in the country due to the quarantine restriction introduction. The study's time range is: the first alternative (excluding quarantine restrictions: quarterly data from the first quarter of 2015 to the fourth quarter of 2019); the second alternative (including quarantine restrictions: quarterly data from the first quarter of 2015 to the second quarter of 2020).

Two indicators are regressors: Gross domestic product (excluding Crimea) in actual prices, million UAH and Unemployed population (according to the methodology of the International Labor Organization), thousand people. The unemployment index is an important parameter of the country's long-term development success (Okuneviciute Neverauskiene \& Rakauskiene, 2018). Twenty-one indicators are regressors.

4 social indicators (Need for workers, thousand people, Employed population aged 1570 years, thousand people, Natural population growth (reduction), Migratory population growth (decline), persons);

12 indicators of capital investment (Rights to commercial designations, industrial property, copyright and related rights, patents, licenses, concessions, etc; Funds from foreign investors; Funds of the population for individual housing; Fisheries; Water transport; Postal and courier activities; Telecommunications; Production of coke and refined petroleum products; Production of computers, electronic and optical products; Production of electrical equipment; Production of motor vehicles, trailers, semi-trailers and other vehicles; Production of furniture and other products, repair and repair installation of machines and equipment);

2 trade indicators (Turnover of retail trade, estimated data; Wholesale and retail motor gasoline, sale of light oil products and gas through gas stations, thousand UAH);

3 indicators of enterprises' expectations (Estimation of changes in sales (turnover) for the previous three months, balance \%; Expected changes in sales (turnover) in the next three months, balance\%; Estimation of current inventories, balance \%).

Eighteen indicators from the above are selected to study the economic and social development transformation direction due to quarantine restrictions. In terms of specific indicators, there are no statistics for the first and second quarters of 2020. The authors collected primary data for further calculations from open sources (State, 2021).

The collinearity study (Table 1) and the correlation analysis on regressand's dependence on each of regressors' indicators (Figure 2) substantiate reasonability to include the specified indicators. One proposes using the program Statistica, Analysis package, Advanced tab methods, tab General linear models of GLM to conduct the key factor identification method.

Table 1 (beta coefficients - column Gross domestic product, excluding Crimea, actual prices million UAH) shows the feasibility to range predictors by their impact degree on the regressor as follows: 1) Wholesale and retail motor gasoline, sale of light petroleum products and gas through gas stations UAH; 2) Production of coke and refined petroleum products; 3 ) Natural increase (reduction); 4) Estimation of changes in sales volume (turnover) for the previous three months, balance \%; 5) Production of computers, electronic and optical products; 6) Rights to commercial designations, industrial property objects rights, copyrights and related rights, patents, licenses, concessions, etc; 7) Water transport; 8) Fisheries; 9) funds from foreign investors; 10) Production of motor vehicles, trailers, semi-trailers and other vehicles; 11) Postal and courier activities; 12) funds of the population for individual housing construction; 13) migratory increase (decrease), axis; 14) Retail trade turnover; 15) The need for employees, thousand people; 16) Telecommunications; 17) Employed population aged 15-70 years, thousand people; 18) Production of electrical equipment; 19) Production of furniture, other products, repair and installation of machinery and equipment; 20) Expected changes in sales (turnover) in the next three months, balance\%; 21) Estimation of the current volume of goods stocks balance, $\%$. 
Table 1. Statistics for the indicator collinearity of the statistical base in the research

\begin{tabular}{|c|c|c|c|c|c|c|c|c|c|}
\hline Effect & Tolernce & Variance & $\mathrm{R}$ square & $\begin{array}{c}\text { GDP, } \\
\text { without } \\
\text { Crimea } \\
\text { at actual } \\
\text { prices, } \\
\text { million } \\
\text { UAH } \\
\text { Beta in } \\
\end{array}$ & $\begin{array}{c}\text { GDP, } \\
\text { without } \\
\text { Crimea } \\
\text { at actual } \\
\text { prices, } \\
\text { million } \\
\text { UAH } \\
\text { Partial } \\
\end{array}$ & $\begin{array}{c}\text { GDP, } \\
\text { without } \\
\text { Crimea } \\
\text { at actual } \\
\text { prices, } \\
\text { million } \\
\text { UAH } \\
\text { Semi-par } \\
\end{array}$ & $\begin{array}{c}\text { Unemplo } \\
\text { yed } \\
\text { populatio } \\
\text { n, } \\
\text { thousand } \\
\text { people } \\
\text { Beta in }\end{array}$ & $\begin{array}{c}\text { Unemplo } \\
\text { yed } \\
\text { populatio } \\
\text { n, } \\
\text { thousand } \\
\text { people } \\
\text { Partial }\end{array}$ & $\begin{array}{c}\text { Unemplo } \\
\text { yed } \\
\text { populatio } \\
\text { n, } \\
\text { thousand } \\
\text { people } \\
\text { Semi-par }\end{array}$ \\
\hline The need for workers, thousand people & 0,012 & 82,454 & 0,988 & 0,081 & 1,000 & 0,009 & 0,067 & 1,000 & 0,007 \\
\hline $\begin{array}{l}\text { Employed population aged } 15-70 \text { years, } \\
\text { thousand people }\end{array}$ & 0,04 & 25,171 & 0,96 & 0,029 & 1,000 & 0,006 & $-0,87$ & $-1,000$ & $-0,168$ \\
\hline Natural increase (reduction), people & 0,007 & 142,505 & 0,993 & $-0,528$ & $-1,000$ & $-0,044$ & 0,684 & 1,000 & 0,057 \\
\hline Migration increase (decrease), people & 0,004 & 241,128 & 0,996 & $-0,126$ & $-1,000$ & $-0,008$ & 0,242 & 1,000 & 0,016 \\
\hline $\begin{array}{l}\text { Rights to commercial designations, } \\
\text { industrial property objects, copyrights } \\
\text { and related rights, patents, licenses, } \\
\text { concessions, etc. }\end{array}$ & 0,045 & 22,013 & 0,955 & $-0,356$ & $-1,000$ & $-0,076$ & 0,004 & 1,000 & 0,001 \\
\hline Funds from foreign investors & 0,025 & 40,48 & 0,975 & $-0,224$ & $-1,000$ & $-0,035$ & 0,238 & 1,000 & 0,037 \\
\hline $\begin{array}{l}\text { Population funds for individual housing } \\
\text { consumption }\end{array}$ & 0,063 & 15,995 & 0,937 & $-0,142$ & $-1,000$ & $-0,036$ & 0,087 & 1,000 & 0,022 \\
\hline Fisheries & 0,017 & 59,416 & 0,983 & $-0,262$ & $-1,000$ & $-0,034$ & 0,235 & 1,000 & 0,03 \\
\hline Water transport & 0,088 & 11,366 & 0,912 & $-0,321$ & $-1,000$ & $-0,095$ & 0,129 & 1,000 & 0,038 \\
\hline Postal and courier activities & 0,035 & 28,418 & 0,965 & 0,144 & 1,000 & 0,027 & $-0,118$ & $-1,000$ & $-0,022$ \\
\hline Telecommunications & 0,013 & 75,987 & 0,987 & 0,03 & 1,000 & 0,004 & 0,231 & 1,000 & 0,027 \\
\hline $\begin{array}{l}\text { Production of coke and refined } \\
\text { petroleum products }\end{array}$ & 0,009 & 106,962 & 0,991 & 0,549 & 1,000 & 0,053 & 0,14 & 1,000 & 0,014 \\
\hline $\begin{array}{l}\text { Production of computers, electronic and } \\
\text { optical products }\end{array}$ & 0,01 & 97,041 & 0,99 & $-0,368$ & $-1,000$ & $-0,037$ & 0,04 & 1,000 & 0,004 \\
\hline Production of electrical equipment & 0,013 & 74,196 & 0,987 & 0,012 & 1,000 & 0,002 & 0,146 & 1,000 & 0,017 \\
\hline $\begin{array}{l}\text { Production of motor vehicles, trailers, } \\
\text { semi-trailers and other vehicles }\end{array}$ & 0,039 & 25,415 & 0,961 & 0,209 & 1,000 & 0,041 & $-0,207$ & $-1,000$ & $-0,041$ \\
\hline $\begin{array}{l}\text { Production of furniture, other products, } \\
\text { repair and installation of machinery and } \\
\text { equipment }\end{array}$ & 0,015 & 68,215 & 0,985 & 0,001 & 1,000 & 0,000 & $-0,153$ & $-1,000$ & $-0,019$ \\
\hline Retail trade turnover & 0,075 & 13,368 & 0,925 & 0,124 & 1,000 & 0,0034 & $-0,128$ & $-1,000$ & $-0,035$ \\
\hline Wholesale and retail Motor gasoline & 0,002 & 540,8 & 0,998 & 1,061 & 1,000 & 0,0046 & $-0,578$ & $-1,000$ & $-0,025$ \\
\hline $\begin{array}{l}\text { Estimation of changes in sales volume } \\
\text { (turnover) for the previous three } \\
\text { months, balance\% }\end{array}$ & 0,011 & 94,411 & 0,989 & 0,459 & 1,000 & 0,047 & $-0,299$ & $-1,000$ & $-0,031$ \\
\hline $\begin{array}{l}\text { Expected changes in sales (turnover) in } \\
\text { the next three months, balance\% }\end{array}$ & $-0,00$ & & & & & & & & \\
\hline $\begin{array}{l}\text { Estimation of the current volume of } \\
\text { stocks of goods, balance\% }\end{array}$ & $-0,00$ & & & & & & & & \\
\hline
\end{tabular}

Source: own construction.

Analysis of the beta coefficients - column Unemployed population, thousand people) indicates the feasibility to range predictors by the degree of their impact on the response as follows: Employed population aged 15-70 years, thousand people; 2) Natural increase (reduction); 3) Wholesale and retail Motor gasoline; Sale of light oil products and gas through gas stations thousand UAH; 4) Estimation of changes in sales volume (turnover) for the previous three months, balance\%; 5) migratory increase (decrease), axis; 6) Funds from foreign investors; 7) Fisheries; 8) Telecommunications; 9) Production of motor vehicles, trailers, semi-trailers and other vehicles; 10) Production of furniture, other products, repair and installation of machinery and equipment; 11) Production of electrical equipment; 12) Production of coke and refined petroleum products; 13) Water transport; 14) Retail trade turnover; 15) Postal and courier activities; 16) funds of the population for individual housing construction; 17) The need for workers, thousand people; 18) Production of computers, electronic and optical products; 19) Rights to commercial designations, objects of industrial property, copyrights and related rights, patents, licenses, concessions, etc ; 20) Expected changes in sales (turnover) in the next three months, balance\%; 21) Estimation of the current volume of stocks of goods, balance\%.

Besides, partial correlation coefficients (columns Gross Domestic Product, excluding Crimea, actual prices of million UAH and Unemployed population, thousand people, Table 1) show the degree of influence of one predictor on the regressor provided that the other 
predictors are fixed. This indicator's calculated values confirm the significant degree of all 21 regressors' influence on the studied regressands.

Analyzing the determination coefficient (column R square of Table 1), i.e., the square of the multiple correlation coefficient between this variable and all others, we note the high significance of all except two: Expected changes in sales (turnover) in the next three months, balance\%; Estimation of the current volume of goods stocks, balance\%. At the same time, the correlation matrix study enables to conclude the following:

the strong direct relationship of gross domestic product with the following indicators: Production of coke and refined products; Production of motor vehicles, trailers, semi-trailers and other vehicles; Expected changes in sales (turnover) in the next three months, balance \%; Estimation of the current volume of stocks of goods, balance\%;

strong inverse relationship of the unemployed population with the following indicators: Employed population aged 15-70 years, thousand people; Expected changes in sales (turnover) in the next three months, balance\%;

the average direct relationship of gross domestic product with the following indicators: The need for workers, thousand people; funds of the population for individual housing construction; Production of computers, electronic and optical products; Production of electrical equipment;

the average inverse relationship of the unemployed population with the following indicators: Production of coke and refined petroleum products; Production of motor vehicles, trailers, semi-trailers and other vehicles.

The authors proposed to evaluate the direction of economic and social development trajectory transformation in the country due to the quarantine restrictions through the data mining by building a neural network. The neural network's economic and mathematical models regarding the dependence between gross domestic product and the unemployed population on factor features are presented using a multilayer perceptron MLP with the BFGS algorithm and based on radial basis functions RBF with the RBFT algorithm.

The economic and mathematical model of the neural network is as follows:

$$
f(x)=F\left(\sum_{i_{N}} w_{i_{N} j_{N} N} \ldots \sum_{i_{2}} w_{i_{2} j_{2} 2} F\left(\sum_{i_{1}} w_{i_{1} j_{1} 1} x_{i_{1} j_{1} 1}-\theta_{j_{1} 1}\right)-\theta_{j_{2} 2} \ldots-\theta_{j_{N} N}\right)
$$

where $F\left(\sum_{i_{1}} w_{i_{1} j_{1} 1} x_{i_{1} j_{1} 1}-\theta_{j_{1} 1}\right)-$ layer 1 ;

$\sum_{i_{2}} w_{i_{2} j_{2} 2} F\left(\sum_{i_{1}} w_{i_{1} j_{1} 1} x_{i_{1} j_{1} 1}-\theta_{j_{1} 1}\right)-\theta_{j_{2} 2}-$ layer 2 ;

$F\left(\sum_{i_{N}} w_{i_{N} j_{N} N} \cdots \sum_{i_{2}} w_{i_{2} j_{2} 2} F\left(\sum_{i_{1}} w_{i_{1} j_{1} 1} x_{i_{1} j_{1} 1}-\theta_{j_{1} 1}\right)-\theta_{j_{2} 2} \ldots-\theta_{j_{N} N}\right)-$ layer N;

i - input number;

$\mathrm{j}$ - number of the neuron in the layer;

$x_{i_{1} j_{1} 1}-\mathrm{i}$-input signal of $\mathrm{j}$-neuron in the layer 1 ;

$w_{i_{N} j_{N} N}$ - weigh coefficient of the $\mathrm{i}$-input of the $\mathrm{j}$-neuron in layer $\mathrm{N}$;

$\theta_{j_{N} N}$ - the threshold level of the $\mathrm{j}$-neuron in layer $\mathrm{N}$.

The economic-mathematical model of the neural network based on radial basis functions is as follows (Michael, 1977; Broomhead \& Lowe, 1988): 


$$
f(x)=\sum_{i=1}^{N} w_{i} \varphi\left(\left\|x-x_{i}\right\|\right)
$$

where $w_{i}$ - weigh coefficient of the i-input signal;

$x_{i}-$ centers of radial basis functions.

Broyden-Fletcher-Goldfarb-Shanno (BFGS) algorithm is used to build a neural network of the multilayer perceptron MLP. It is one of the most common quasi-Newton methods for implementing an iterative numerical optimization procedure to find a nonlinear function's local extremum without restrictions. The BFGS algorithm involves the following steps (Zhang et al., 2020):

determination of weight coefficients by random small quantities and the initial value of the inverse Hessian approximation $\mathrm{V}$ - matrix of $\mathrm{n} \times \mathrm{n}$ size, where $\mathrm{n}$ is the length of the gradient vector $\mathrm{g}$.

calculation of the gradient $\mathrm{g}$.

calculation of the weight coefficients correlation $\Delta W=g \cdot \tau, W_{k+1}=W_{k}-\Delta W$, where $\tau$ is the parameter of learning speed.

determining the new value of the gradient $g=g(W)$, considering the previous value of $g_{p}$, and calculating the change in the gradient $\Delta g=g-g_{p}$.

calculation of the inverse Hessian ( $\mathrm{r}$ change of gradient, s change of weights):

$$
\begin{gathered}
V_{k+1}=V_{k}-\frac{V_{k} \cdot s \cdot s^{T} \cdot V_{k}}{s^{T} \cdot V_{k} \cdot s}+\frac{r \cdot r^{T}}{s^{T} \cdot s} \\
r=\Delta g_{k}=g_{k}-g_{k-1} \\
s=\Delta W_{k}=W_{k}-W_{k-1}
\end{gathered}
$$

calculation of changes in weight coefficients $\Delta W=W \cdot g$ and adjustment of parameters $W=W-\Delta W$.

determination of the error. If the error of the specified accuracy exceeds, it is necessary to repeat the algorithm, starting with step 4. Otherwise, the algorithm stops.

The RBFT algorithm is used to build a neural network based on the radial basis functions of RBF.

It is proposed to use the Statistica program's capabilities, the Analysis package, the Neural Networks tab, and the Regression tab to implement this stage.

\section{Empirical results}

For practical approbation of the design calculations to forecast the levels of gross domestic product and unemployed population from the first quarter of 2020 to the fourth quarter of 2022 in Ukraine, the authors conducted economic and mathematical modeling of two types of neural networks (multilayer MLP perceptron and network based on radial basis functions ) of regression dependence of gross domestic product and the unemployed population on the relevant regressors. They systematized the results in tabular form (table 2).

Table 2 shows a much greater range of constructed neural networks in the form of a multilayer perceptron MLP (9 of 13, 69.23\% of models), than networks based on radial basis functions RBF (30.77\% of models). All presented models (except for 6, 7 and 8, 11) are characterized by a high level of adequacy, evidenced by the criteria in the columns "Productivity training", "Productivity control". At the same time, the performance of MLP models has a much smaller variation range of correlation coefficients - from 0.9368 to 0.9999 (training sample), from 0.9702 to 0.9845 (test sample) than RBF models - respectively, from 
0.1829 to 0.7086 (training sample), from 0.5379 to 0.9846 (test sample). The reliability of the constructed neural networks is also confirmed by the error rate within the training, control and test sample, which takes values close to zero.

The authors chose all 13 models for forecasting the gross domestic product and the unemployed population from the first quarter of 2020 to the fourth quarter of 2022 . The BFGS algorithm is used to construct a neural network of the MLP multilayer perceptron type, and respectively, the RBFT algorithm is used for a neural network based on the radial basis functions of RBF. We will demonstrate a fragment from the neural network architecture regarding the perspective layer of 21 layers with five hidden layers of MLP 21-5 in Figure 1.

Table 2. The results of neural network models for regression dependence of gross domestic product and unemployed population on relevant regressors

\begin{tabular}{|c|c|c|c|c|c|c|c|c|c|}
\hline Index & Architecture & $\begin{array}{c}\text { Producti- } \\
\text { vity } \\
\text { training }\end{array}$ & $\begin{array}{l}\text { Productivity } \\
\text { control }\end{array}$ & $\begin{array}{c}\text { Training } \\
\text { error }\end{array}$ & Test error & $\begin{array}{c}\text { Training } \\
\text { algorithm }\end{array}$ & $\begin{array}{l}\text { Error } \\
\text { function }\end{array}$ & $\begin{array}{l}\text { Hidden } \\
\text { activation }\end{array}$ & $\begin{array}{l}\text { Output } \\
\text { activation }\end{array}$ \\
\hline 1 & MLP 21-5-2 & 0.973187 & 0.977594 & 0.004519 & 0.012485 & BFGS 13 & SOS & Sine & Identity \\
\hline 2 & MLP 21-5-2 & 0.999999 & 0.975184 & 0.000000 & 0.006793 & BFGS 131 & SOS & Exponential & Sine \\
\hline 3 & MLP 21-6-2 & 0.936821 & 0.970242 & 0.009444 & 0.013917 & BFGS 11 & SOS & Sine & Tanh \\
\hline 4 & MLP 21-5-2 & 0.991670 & 0.980823 & 0.001399 & 0.012250 & BFGS 18 & SOS & Tanh & Sine \\
\hline 5 & MPL 21-5-2 & 0.984664 & 0.975821 & 0.002429 & 0.014108 & BFGS 26 & SOS & Logistic & Logistic \\
\hline 6 & RBF 21-5-2 & 0.182852 & 0.537886 & 0.074342 & 0.123409 & RBFT & SOS & Gaussian & Identity \\
\hline 7 & RBF 21-5-2 & 0.463001 & 0.652043 & 0.074342 & 0.123409 & RBFT & SOS & Gaussian & Identity \\
\hline 8 & RBF 21-5-2 & 0.446046 & 0.735705 & 0.074342 & 0.123409 & RBFT & SOS & Gaussian & Identity \\
\hline 9 & MLP 21-5-2 & 0.999841 & 0.979002 & 0.000026 & 0.010508 & BFGS 35 & SOS & Exponential & Exponential \\
\hline 10 & MLP 21-5-2 & 0.964678 & 0.983086 & 0.005649 & 0.012953 & BFGS 9 & SOS & Identity & Tanh \\
\hline 11 & RBF 21-5-2 & 0.708576 & 0.975072 & 0.037124 & 0.043064 & RBFT & SOS & Gaussian & Identity \\
\hline 12 & MLP 21-6-2 & 0.991946 & 0.976478 & 0.001359 & 0.011874 & BFGS 27 & SOS & Logistic & Logistic \\
\hline 13 & MLP 21-6-2 & 0.968505 & 0.984588 & 0.005201 & 0.008732 & BFGS 8 & SOS & Identity & Sine \\
\hline
\end{tabular}

Source: own construction.

Table 3. Fragment from the neural network architecture of the MLP 21-5-2 (multilayer perceptron of 21 layers with five hidden layers)

Network weights

Connections
1. MLP 21-5-2

Weight values

1. MLP 21-5-2

1 The need for workers, thousand people $\rightarrow$ hidden neuron $-0,057008$

2 The need for workers, thousand people $\rightarrow$ hidden neuron 2

$-0,174539$

3 The need for workers, thousand people $\rightarrow$ hidden neuron 3

$-0,010515$

4 The need for workers, thousand people $\rightarrow$ hidden neuron 4

0,011973

5 The need for workers, thousand people $\rightarrow$ hidden neuron 5

$-0,036693$

6 Population aged 15-70 years, thousand people $\rightarrow$ hidden neuron 1

$-0,029574$

7 Population aged 15-70 years, thousand people $\rightarrow$ hidden neuron 2

0,152916

8 Population aged 15-70 years, thousand people $\rightarrow$ hidden neuron 3

0,202181

9 Population aged 15-70 years, thousand people $\rightarrow$ hidden neuron 4

0,007077

10 Population aged 15-70 years, thousand people $\rightarrow$ hidden neuron 5

0,199111

11 Natural increase (reduction) $\rightarrow$ hidden neuron 1

$-0,129421$

12 Natural increase (reduction) $\rightarrow$ hidden neuron 2

0,086522

13 Natural increase (reduction) $\rightarrow$ hidden neuron 3

0,158329

14 Natural increase (reduction) $\rightarrow$ hidden neuron 4

0,005035

15 Natural increase (reduction) $\rightarrow$ hidden neuron 5

0,007741

16 Migration increase (reduction) $\rightarrow$ hidden neuron 1

0,014024

17 Migration increase (reduction) $\rightarrow$ hidden neuron 2

$-0,086780$

18 Migration increase (reduction) $\rightarrow$ hidden neuron 3

$-0,044901$

19 Migration increase (reduction) $\rightarrow$ hidden neuron 4

0,146937

$20 \quad$ Migration increase (reduction) $\rightarrow$ hidden neuron 5

0,046278

21 Rights to commercial designations, industrial property objects, copyrights and related rights, patents, licenses, concessions, etc. $\rightarrow$ hidden neuron 1

22 Rights to commercial designations, industrial property objects, copyrights and related rights, patents, licenses, concessions, etc. $\rightarrow$ hidden neuron 2 


\begin{tabular}{clc}
\hline 23 & $\begin{array}{l}\text { Rights to commercial designations, industrial property objects, copyrights and related rights, } \\
\text { patents, licenses, concessions, etc. } \rightarrow \text { hidden neuron 3 }\end{array}$ & 0,283452 \\
\hline 24 & $\begin{array}{l}\text { Rights to commercial designations, industrial property objects, copyrights and related rights, } \\
\text { patents, licenses, concessions, etc. } \rightarrow \text { hidden neuron 4 }\end{array}$ & $-0,258651$ \\
\hline 25 & $\begin{array}{l}\text { Rights to commercial designations, industrial property objects, copyrights and related rights, } \\
\text { patents, licenses, concessions, etc. } \rightarrow \text { hidden neuron 5 }\end{array}$ & 0,254409 \\
\hline
\end{tabular}

Source: own construction.

The scattering diagram of theoretical (obtained by using constructed neural networks) and actual gross domestic product values and the unemployed population is in Fig. 1-2. Based on the visual ratio of neural networks to forecast gross domestic product and the unemployed population, it is possible to conclude about the reliability of the selected models, as evidenced by the closeness of actual values compared to theoretical ones (predictive, found using models except for the 8th model).

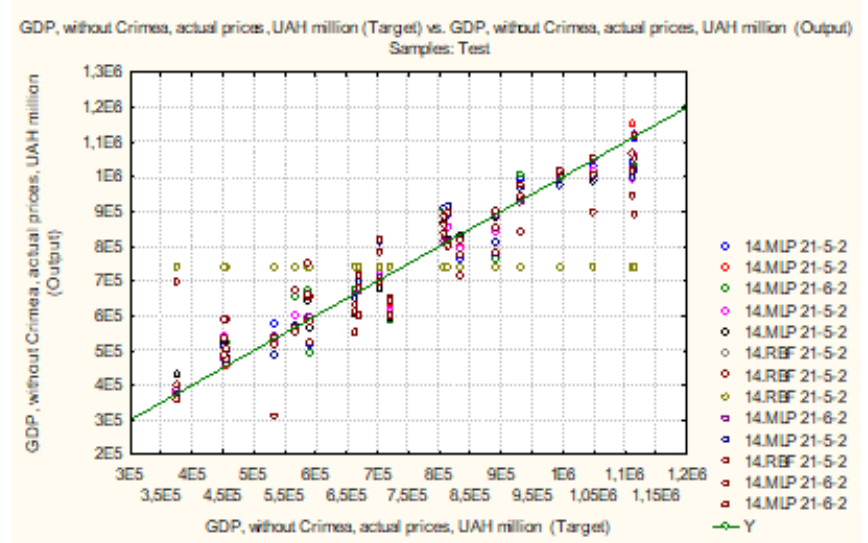

Figure 1. The ratio of actual and predicted gross domestic product Source: own construction.

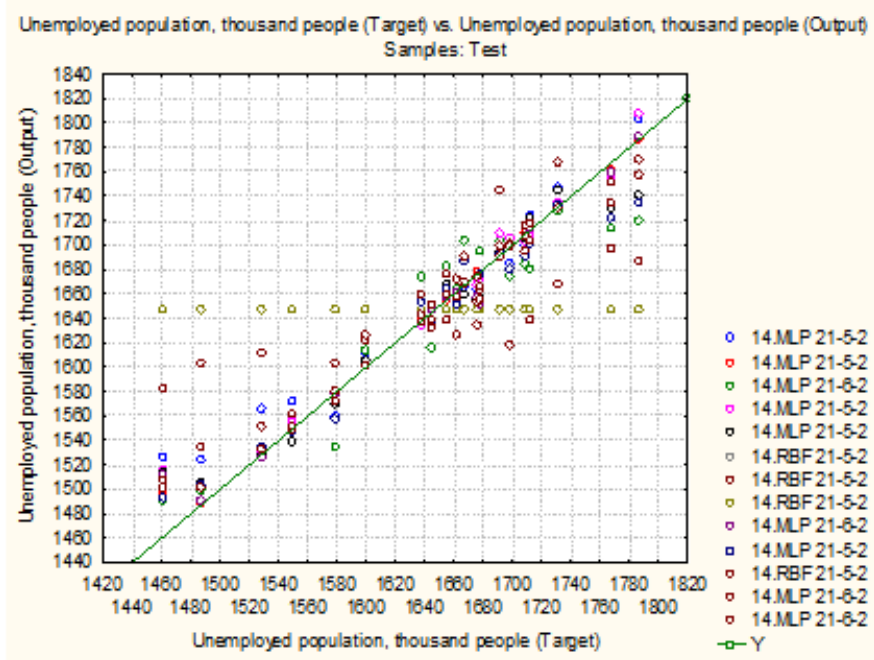

Figure 2. The ratio of actual and forecast levels of the unemployed population Source: own construction.

In terms of calculation approbation to forecast the gross domestic product levels and the unemployed population during the 3rd quarter of 2020 - the 4th quarter of 2022, we will conduct economic and mathematical modeling of two neural networks (multilayer MLP perceptron and RBF network) regression dependence of gross domestic product and the unemployed population on relevant regressors and systematize the results in Table 3 . The data 
from Table 4 shows a much greater range of constructed neural networks via multilayer perceptron MLP (10 of 13, 76.92\% of models), than networks based on radial basis functions RBF (23.08\% of models). A high level of adequacy characterizes all presented models (except for 6, 7 and 8), as evidenced by the criteria in the columns "Productivity training", "Productivity control". At the same time, the performance of MLP models has a smaller range of correlation coefficients variation - from 0.8831 to 0.9989 (training sample), from 0.8136 to 0.9335 (test sample), than RBF models - respectively, from - 0.0433 to 0.0.2837 (training sample), from -0.2485 to 0.1971 (test sample). The reliability of the constructed models of neural networks is also confirmed by the error rate within the training, control and test sample, which takes values close to zero. We will choose all thirteen models to forecast gross domestic product and the unemployed population during the third quarter of 2020 - the fourth quarter of 2022.

Table 4. The results of neural network models for regression dependence of gross domestic product and the unemployed population on regressors during the first quarter of 2015 - the second quarter of 2020

\begin{tabular}{|c|c|c|c|c|c|c|c|c|c|}
\hline Index & Architecture & $\begin{array}{l}\text { Productivity } \\
\text { training }\end{array}$ & $\begin{array}{c}\text { Productivity } \\
\text { control }\end{array}$ & $\begin{array}{c}\text { Training } \\
\text { error }\end{array}$ & $\begin{array}{l}\text { Test } \\
\text { error }\end{array}$ & $\begin{array}{c}\text { Training } \\
\text { algorithm }\end{array}$ & $\begin{array}{c}\text { Error } \\
\text { function }\end{array}$ & $\begin{array}{c}\text { Hidden } \\
\text { activation }\end{array}$ & $\begin{array}{c}\text { Output } \\
\text { activation }\end{array}$ \\
\hline 1 & MLP 18-12-2 & 0.927752 & 0.854923 & 0.016645 & 0.015460 & BFGS 8 & SOS & Logistic & Sine \\
\hline 2 & MLP 18-17-2 & 0.920189 & 0.838053 & 0.015770 & 0.012349 & BFGS 9 & SOS & Logistic & Tanh \\
\hline 3 & MLP 18-8-2 & 0.994539 & 0.860934 & 0.000944 & 0.009592 & BFGS 25 & SOS & Tanh & Tanh \\
\hline 4 & MLP 18-8-2 & 0.910821 & 0.876994 & 0.014532 & 0.016738 & BFGS 4 & SOS & Exponential & Logistic \\
\hline 5 & MPL 18-13-2 & 0.965576 & 0.829655 & 0.008444 & 0.012170 & BFGS 9 & SOS & Identity & Identity \\
\hline 6 & RBF 18-5-2 & -0.043267 & 0.197068 & 0.081188 & 0.043034 & RBFT & SOS & Gaussian & Identity \\
\hline 7 & RBF 18-5-2 & 0.283654 & -0.222331 & 0.081188 & 0.043034 & RBFT & SOS & Gaussian & Identity \\
\hline 8 & RBF 18-5-2 & 0.203114 & -0.248472 & 0.081188 & 0.043034 & RBFT & SOS & Gaussian & Identity \\
\hline 9 & MLP 18-9-2 & 0.965931 & 0.813610 & 0.006140 & 0.014978 & BFGS 10 & SOS & Sine & Sine \\
\hline 10 & MLP 18-9-2 & 0.883066 & 0.824617 & 0.022561 & 0.012645 & BFGS 6 & SOS & Tanh & Identity \\
\hline 11 & MLP 18-14-2 & 0.911598 & 0.842332 & 0.014001 & 0.013891 & BFGS 6 & SOS & Tanh & Logistic \\
\hline 12 & MLP 18-8-2 & 0.998924 & 0.933467 & 0.000177 & 0.011308 & BFGS 29 & SOS & Tanh & Sine \\
\hline 13 & MLP 18-14-2 & 0.920963 & 0.893228 & 0.016035 & 0.005787 & BFGS 6 & SOS & Sine & Identity \\
\hline
\end{tabular}

Source: own construction.

The scattering diagram of theoretical (obtained by using the formed 13 neural networks) and actual gross domestic product values and the unemployed population is shown in Figures 3-4.

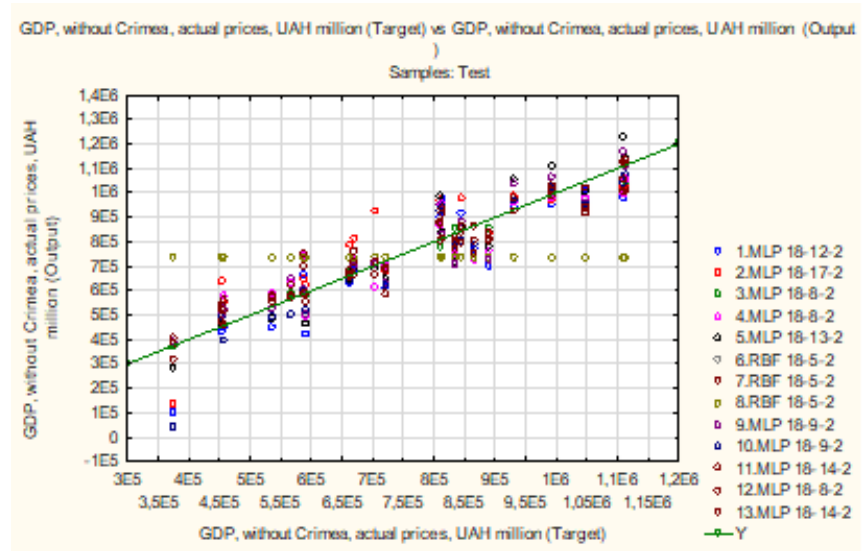

Figure 3. The ratio of actual and forecast levels of the gross domestic product during the third quarter of 2020 - the fourth quarter of 2022

Source: own construction. 


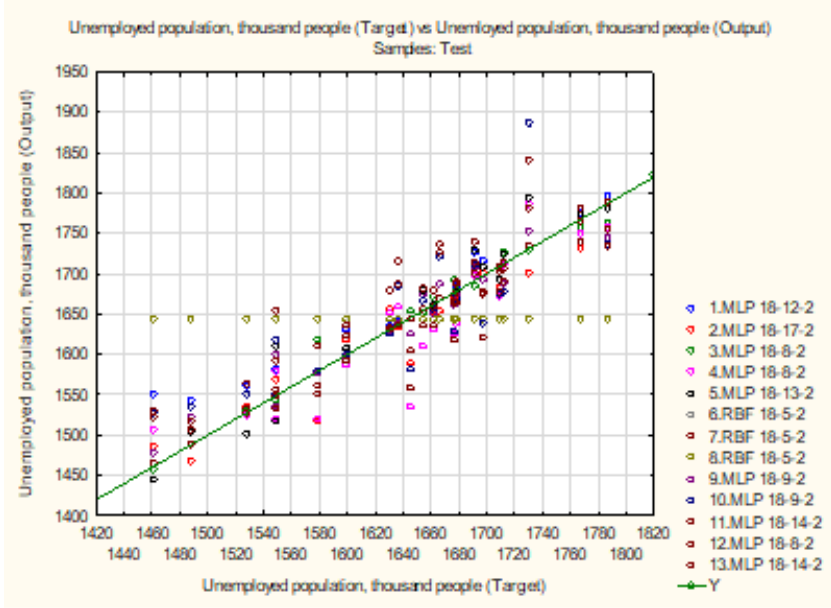

Figure 4. The ratio of actual and forecast levels of the gross domestic product during the third quarter of 2020 - the fourth quarter of 2022

Source: own construction.

The quality of the constructed neural network models is based on data from Table 5 correlation coefficients of actual and forecast levels in terms of 13 neural network models to predict the levels of gross domestic product and unemployed population during the first quarter of 2015 - second quarter of 2020 . The third quarter of 2020 - fourth quarter of 2022 is the best period to forecast: for gross domestic product - the third model with MLP architecture 18-8-2, the fifth model with MLP architecture 18-13-2, the ninth model with MLP architecture 18-9-2, the twelfth model with MLP 18-8-2 architecture; for the unemployed population - the second model with the architecture MLP 18-17-2, the third model with the architecture MLP 18-8-2, the fifth model with the architecture MLP 18-13-2, the ninth model with the architecture MLP 18-9-2, the twelfth model with the MLP 18-8-2 architecture.

Table 5. Correlation coefficients in the context of 13 constructed neural network models for forecasting the gross domestic product and the unemployed population levels during the first quarter of 2015 - the second quarter of 2020

\begin{tabular}{cccc}
\hline Index & Architecture & $\begin{array}{c}\text { GDP, without Crimea, actual } \\
\text { prices, UAH million } \\
\text { Train }\end{array}$ & $\begin{array}{c}\text { Unemployed population, thousand } \\
\text { people } \\
\text { Train }\end{array}$ \\
\hline 1 & MLP 18-12-2 & 0.924098 & 0.931405 \\
\hline 2 & MLP 18-17-2 & 0.875098 & 0.965281 \\
\hline 3 & MLP 18-8-2 & 0.994321 & 0.994757 \\
\hline 4 & MLP 18-8-2 & 0.916550 & 0.905092 \\
\hline 5 & MLP 18-13-2 & 0.966086 & 0.965067 \\
\hline 6 & RBF 18-5-2 & -0.496990 & 0.410456 \\
\hline 7 & RBF 18-5-2 & 0.513691 & 0.053616 \\
\hline 8 & RBF 18-5-2 & 0.050744 & 0.355485 \\
\hline 9 & MLP 18-9-2 & 0.965781 & 0.966080 \\
\hline 10 & MLP 18-9-2 & 0.947420 & 0.818713 \\
\hline 11 & MLP 18-14-2 & 0.947584 & 0.875612 \\
\hline 12 & MLP 18-8-2 & 0.998991 & 0.998856 \\
\hline 13 & MLP 18-14-2 & 0.955512 & 0.886414 \\
\hline
\end{tabular}

Source: own construction.

The authors compared two scenarios having predicted the value of the gross domestic product and the unemployed population in different scenarios considering the first and second quarters of 2020 and without considering it, i.e., the first quarantine wave and without it. Figure 5 and Table 6 present the obtained values. 


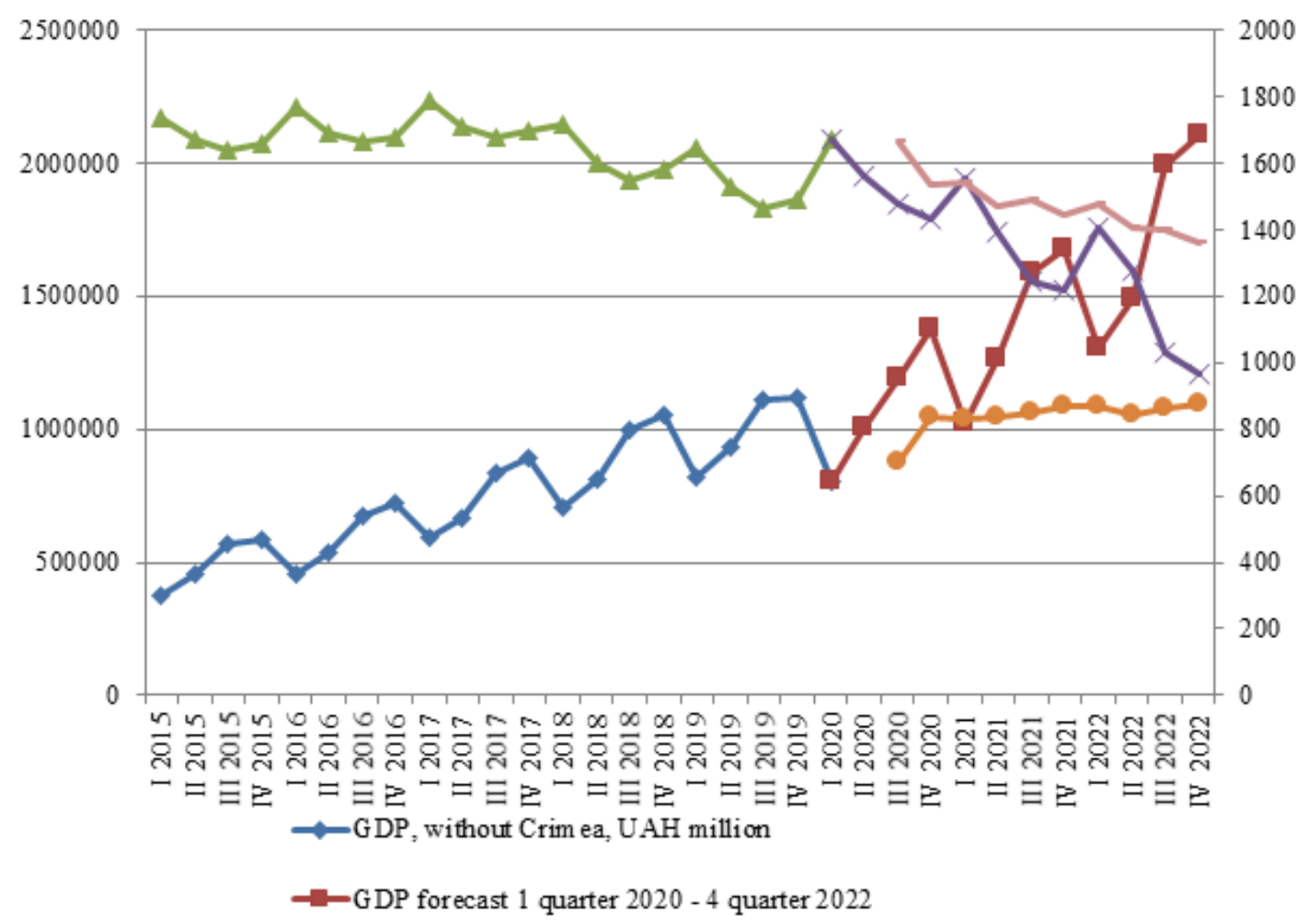

Figure 5. The ratio of actual (up to the 2nd quarter of 2020 and the 4th quarter of 2019) and forecast levels (from the 3rd quarter of 2020 and the 1st quarter of 2020) in terms of gross domestic product and unemployed population Source: own construction. 
Table 6. Comparison of actual and forecast values of gross domestic product and unemployed population in different scenarios (considering the first and second quarters of 2020 and without considering it)

\begin{tabular}{|c|c|c|c|c|c|c|c|c|}
\hline Period & $\begin{array}{l}\text { GDP, } \\
\text { without } \\
\text { Crimea, } \\
\text { UAH } \\
\text { million }\end{array}$ & $\begin{array}{c}\text { GDP } \\
\text { forecast } 1 \\
\text { quarter } \\
2020-4 \\
\text { quarter } \\
2022\end{array}$ & $\begin{array}{c}\text { UP, } \\
\text { thousand } \\
\text { people }\end{array}$ & $\begin{array}{c}\text { UP } \\
\text { forecast } 1 \\
\text { quarter } \\
2020-4 \\
\text { quarter } \\
2022\end{array}$ & $\begin{array}{l}\text { GDP, } \\
\text { without } \\
\text { Crimea, } \\
\text { UAH } \\
\text { million }\end{array}$ & $\begin{array}{c}\text { GDP } \\
\text { forecast } 3 \\
\text { quarter } \\
2020-4 \\
\text { quarter } \\
2022\end{array}$ & $\begin{array}{l}\text { UP, } \\
\text { thousand } \\
\text { people }\end{array}$ & $\begin{array}{c}\text { UP, } \\
\text { forecast } 3 \\
\text { quarter } \\
2020-4 \\
\text { quarter } \\
2022\end{array}$ \\
\hline 1 & 2 & 3 & 4 & 5 & 6 & 7 & 8 & 9 \\
\hline I 2015 & 375,991 & & 1731.53 & & 375,991 & & 1731.53 & \\
\hline II 2015 & 456,715 & & 1667.3 & & 456,715 & & 1667.3 & \\
\hline III 2015 & 566,997 & & 1637.6 & & 566,997 & & 1637.6 & \\
\hline IV 2015 & 588,841 & & 1654.7 & & 588,841 & & 1654.7 & \\
\hline I 2016 & 455,298 & & 1767.4 & & 455,298 & & 1767.4 & \\
\hline II 2016 & 535,701 & & 1691.5 & & 535,701 & & 1691.5 & \\
\hline III 2016 & 671,456 & & 1662.2 & & 671,456 & & 1662.2 & \\
\hline IV 2016 & 722,912 & & 1678.2 & & 722,912 & & 1678.2 & \\
\hline I 2017 & 592,523 & & 1786.9 & & 592,523 & & 1786.9 & \\
\hline II 2017 & 665,233 & & 1709.7 & & 665,233 & & 1709.7 & \\
\hline III 2017 & 834,287 & & 1676.9 & & 834,287 & & 1676.9 & \\
\hline IV 2017 & 891,839 & & 1698 & & 891,839 & & 1698 & \\
\hline I 2018 & 705,977 & & 1712.8 & & 705,977 & & 1712.8 & \\
\hline II 2018 & 810,174 & & 1600.4 & & 810,174 & & 1600.4 & \\
\hline III 2018 & 994,810 & & 1549.3 & & 994,810 & & 1549.3 & \\
\hline IV 2018 & $1,049,635$ & & 1578.6 & & $1,049,635$ & & 1578.6 & \\
\hline I 2019 & 815,123 & & 1645.8 & & 815,123 & & 1645.8 & \\
\hline II 2019 & 932,677 & & 1528.4 & & 932,677 & & 1528.4 & \\
\hline III 2019 & $1,111,862$ & & 1461.8 & & $1,111,862$ & & 1461.8 & \\
\hline IV 2019 & $1,114,902$ & & 1487.7 & & $1,114,902$ & & 1487.7 & \\
\hline I 2020 & 800,106 & 800,106 & 1670.001 & 1670.001 & 845,829 & & 1548.9 & \\
\hline II 2020 & & $1,004,658$ & & 1560.546 & 867,782 & & 1630.6 & \\
\hline III 2020 & & $1,187,562$ & & 1474.36 & 873,664 & 873,664 & 1660.887 & 1660.887 \\
\hline IV 2020 & & $1,376,318$ & & 1428.437 & & $1,045,236$ & & 1533.188 \\
\hline I 2021 & & $1,018,460$ & & 1552.818 & & $1,034,628$ & & 1541.794 \\
\hline II 2021 & & $1,259,700$ & & 1391.175 & & $1,0437,39$ & & 1466.629 \\
\hline III 2021 & & $1,587,115$ & & 1240.777 & & $1,062,303$ & & 1491.793 \\
\hline IV 2021 & & $1,674,015$ & & 1214.733 & & $1,084,077$ & & 1445.972 \\
\hline I 2022 & & $1,305,531$ & & 1406.675 & & $1,083,250$ & & 1474.098 \\
\hline II 2022 & & $1,491,635$ & & 1275.096 & & $1,053,416$ & & 1402.191 \\
\hline III 2022 & & $1,990,795$ & & 1030.87 & & $1,079,408$ & & 1399.283 \\
\hline IV 2022 & & $2,101,626$ & & 963.243 & & $1,092,791$ & & 1357.648 \\
\hline
\end{tabular}

Source: own construction.

\section{Conclusions}

Adjustment of national and local post-quarantine recovery programs requires considering the time factor regarding macro indicators changes and deep deformation resulting from quarantine and cause macroeconomic trends in 2020-2022. The authors formalize the dependence of the GDP and unemployment levels on social and economic development indicators of Ukraine through neural networks of two types: 1) in the form of a multilayer MLP perceptron (the weight coefficients of the input channels will be determined by small random values, the correlation of weights is considered when estimating the parameter "learning speed", the possible dynamic change of weight coefficients is considered 
by adjusting the parameters, the error thresholds are determined); 2) based on the radial basis functions of RBF using the RBFT algorithm (considering the weight coefficients of each input signal, the centers of radial basis functions, and the threshold levels of each neuron in the corresponding layer). Constructed neural networks differ in architecture (number of layers and hidden neurons), performance and error, learning algorithm and error functions, active hidden and active source neurons. The authors' approach is fundamentally different from the existing ones due to the application of an iterative procedure of numerical optimization, taking into account the possible dynamic change of input parameters and parallel processing of this information by a large number of neurons. Consideration in the process of modeling migration processes and the need for workers creates a basis for operational and targeted decisions to limit the mobility of the population in the event of new waves of the pandemic and adjust government programs to stimulate job creation in the regions. Considering the complexity of economic parameters and their connection with the level of vulnerability from COVID-19 will allow adjusting the initiatives of sectoral and functional support to increase the regions' financial and economic self-sufficiency.

Thus, the urgent task is to forecast the trajectory of significant economic and social indicators development affected by the COVID-19 pandemic based on the neural networks. This approach is a powerful and flexible tool for ensuring an effective system of antiepidemic government measures. The method proposed by the authors makes it possible to identify complex dependencies of socio-economic processes within the state to predict the possible results of the approved quarantine measures. Its use can increase the initial validity of public administration decisions, preventing the pandemic's negative impact. The author's approach effectively predicts quarantine measures on changing individual countries' social and economic development in different future epidemiological threats.

\section{References}

Afanasyev, M.Y., Alexander V. Kudrov, A.V. (2020). Estimates of economic complexity in the structure of the regional economy. Montenegrin Journal of Economics, 16(4), 43-53. doi:10.14254/1800-5845/2020.16-4.4.

Balas, A.N., Kaya, H.D. (2019). The global economic crisis and retailers' security concerns: the trends. SocioEconomic Challenges, 3(2), 5-14. http://doi.org/10.21272/sec.3(2).514.2019.

Bazyliuk, V., Shtangret, A., Sylkin, O., \& Bezpalko, I. (2019). Comparison of institutional dynamics of regional development publishing and printing activities in Ukraine: methodological and practical aspects. Business: Theory and Practice, 20, 116-122. https://doi.org/10.3846/btp.2019.11.

Broomhead, D.H., Lowe, D. (1988). Multivariable functional interpolation and adaptive networks. Complex Systems, 2, 321-355.

Cek, K., \& Eyupoglu, S. (2020). Does environmental, social and governance performance influence economic performance? Journal of Business Economics and Management, 21(4), 1165-1184. https://doi.org/10.3846/jbem.2020.12725.

Censolo, R. \& Morelli, M. (2020). COVID-19 and the potential consequences for social stability. Peace Economics, Peace Science and Public Policy, 26(3). https://doi.org/10.1515/peps-2020-0045.

Cepel, M., Gavurova, B., Dvorsky, J., \& Belas, J. (2020).The impact of the COVID-19 crisis on the perception of business risk in the SME segment. Journal of International Studies, 13(3), 248-263. doi:10.14254/2071-8330.2020/13-3/16.

Dave, H. (2019). The X-ray report of "Economic growth". Financial Markets, Institutions and Risks, 3(4), 89-93. http://doi.org/10.21272/fmir.3(4).89-93.2019. 
Deyneka, T., Shkurupii, O., Verhal, K. \& Bazavluk, N. (2019). Global status of countries: determination and interpretation. Marketing and Management of Innovations, 4, 216228. http://doi.org/10.21272/mmi.2019.4-17.

Didenko, I., Volik, K., Vasylieva, T., Lyeonov, S., \& Antoniuk, N. (2020). Migration, environment, and country safety: Analysis of touchpoints. Paper presented at the E3S Web of Conferences, 202. doi:10.1051/e3sconf/202020203028.

Dinu, V., Virlanuta, F.O., Zamfir, C., Stanciu, S., Guven, E. T. A., \& Yatbaz, A. (2020). Measuring the impact of social progress on the recycling rate at European level by using econometric models. Transformations in Business \& Economics, 19, 535-550.

Djalilov, K., Lyeonov, S., \& Buriak, A. (2015). Comparative studies of risk, concentration and efficiency in transition economies. Risk Governance and Control: Financial Markets and Institutions, 5(4CONT1), 178-187. doi:10.22495/rgcv5i4c1art7.

Dutta, P., Dutta, U., Hasan, S., Sarkar, S., \& Sana, T. (2020). Educate, empower and protect people through timely authentic information: explore how Bangladeshi newspapers response to COVID-19 pandemic. SocioEconomic Challenges, 4(3), 93103. https://doi.org/10.21272/sec.4(3).93-103.2020.

Greco, F. (2018). Resilience: Transform adverse events into an opportunity for growth and economic sustainability through the adjustment of emotions. Business Ethics and Leadership, 2(1), 44-52. Doi: 10.21272/bel.2(1).44-52.2018.

Haller, A. (2020). From classical and neoclassical economic growth to degrowth in Europe. Challenges for public administration. Administratie si Management Public, 34, 150-170. DOI: $10.24818 / \mathrm{amp} / 2020.34-9$.

Harust, Yu., Melnyk, V. (2019). Economic security of the country: marketing, institutional and political determinants. Marketing and Management of Innovations, 4, 373-382. http://doi.org/10.21272/mmi.2019.4-29.

Hashim Sabo Bello, Nura Ahmad, Ibrahim Suleiman Galadima. (2018). Islamic economy as an alternative solution to managing economic crisis: Some fashionable case studies of Iran, Malaysia Saudi Arabia. Financial Markets, Institutions and Risks, 2(3), 43-51. DOI: $10.21272 /$ fmir.2(3).43-51.2018.

Hruschka, H. (1993). Determining market response functions by neural network modeling: A comparison to econometric techniques. European Journal of Operational Research, 66, 27-35.

Iacobuta, A.O., Mursa, G.C., Mihai, C., Cautisanu, C., \& Cismas, L.M. (2019). Institutions and sustainable development: a cross-country analysis. Transformations in Business \& Economics, 18, 628-646.

Jafarzadeh, E., He, Shuquan (2019). The impact of income inequality on the economic growth of Iran: an empirical analysis. Business Ethics and Leadership, 3(2), 53-62. http://doi.org/10.21272/bel.3(2).53-62.2019.

Kouassi, K.B. (2018). Public spending and economic growth in developing countries: a synthesis. Financial Markets, Institutions and Risks, 2(2), 22-30. DOI: 10.21272/fmir.2(2).22-30.2018.

Kowo, S.A., Kadiri B.I., Zekeri, A. (2020). Correlate of workforce diversity and organisational performance of multinational food producing industry in $\begin{array}{llll}\text { Nigeria. Business } \quad \text { Ethics and Leadership, } 4(1), & 126-137 .\end{array}$ http://doi.org/10.21272/bel.4(1).126-137.2020.

Kryshtanovych, M., Filippova, V., Huba, M., Kartashova, O., \& Molnar, O. (2020). Evaluation of the implementation of the circular economy in EU countries in the context of sustainable development. Business: Theory and Practice, 21(2), 704-712. https://doi.org/10.3846/btp.2020.12482. 
Kuc-Czarnecka, M. (2020). COVID-19 and digital deprivation in Poland. Oeconomia Copernicana, 11(3), 415-431. https://doi.org/10.24136/oc.2020.017.

Kufel, T. (2020). ARIMA-based forecasting of the dynamics of confirmed Covid-19 cases for selected European countries. Equilibrium. Quarterly Journal of Economics and Economic Policy, 15(2), 181-204. https://doi.org/10.24136/eq.2020.009.

Kuzmenko, O., Vasylieva, T., Vojtovič, S., Chygryn, O., \& Snieška, V. (2020). Why do regions differ in vulnerability to Covid-19? Spatial nonlinear modeling of social and economic patterns. Economics and Sociology, 13(4), 318-340. doi:10.14254/2071789X.2020/13-4/20.

Leach, M., MacGregor, Scoones Ia., \& Wilkinson A. (2021). Post-pandemic transformations: how and why COVID-19 requires to rethink development. World Development, 138, https://doi.org/10.1016/j.worlddev.2020.105233.

Lopez, B.S., Alcaide, A.V. (2020). Blockchain, AI and IoT to improve governance, financial management and control of crisis: case study COVID-19. SocioEconomic Challenges, 4(2), 78-89. https://doi.org/10.21272/sec.4(2).78-89.2020.

Luxhoy, J.T., Riis, J.O., \& Stensballe, B. (1996). A hybrid econometric-neural network modeling approach for sales forecasting. International Journal Production Economics, 43, 175-192.

Mach, Ł. (2019). Measuring and assessing the impact of the global economic crisis on European real property market. Journal of Business Economics and Management, 20(6), 1189-1209. https://doi.org/10.3846/jbem.2019.11234.

Malyarets, L.M., Barannik, I.O., Sabadash, L.O., \& Grynko, P.O. (2019). Modeling the Economic Sustainability of the Macro System (for Example Ukraine). Montenegrin Journal of Economics, 14(3), 23-35. DOI: 10.14254/1800-5845/2019.15-3.2.

Marcel, D.T. Am. (2019). The determinant of economic growth evidence from Benin: Time series analysis from 1970 to 2017. Financial Markets, Institutions and Risks, 3(1), 6374. http://doi.org/10.21272/fmir.3(1).63-74.2019.

Medani P. Bhandari (2019). Sustainable development: Is this paradigm the remedy of all challenges? Does its goals capture the essence of real development and sustainability? With reference to discourses, creativeness, boundaries and institutional architecture. SocioEconomic Challenges, 3(4), 97-128. http://doi.org/10.21272/sec.3(4).97-128.2019.

Michael, J.D. Powell. (1977). Restart procedures for the conjugate gradient method. Mathematical Programming, 12, 241-254. DOI:10.1007/bf01593790.

Mikhaylova, A.A., Mikhaylov, A.S., Savchina, O.V., \& Plotnikova, A.P. (2019). Innovation landscape of the Baltic region. Administratie si Management Public, (33), 165-180, DOI: $10.24818 / \mathrm{amp} / 2019.33-10$.

Mikhnevych, L., Marchenko, V. Hristov, P., \& Kuzior, A. (2020). Conceptual relationships between country mage and economic security. Marketing and Management of Innovations, 1, 285-293. https://doi.org/10.21272/mmi.2020.1-24.

Mofijur, M., Rizwanul Fattah, I.M., Asraful Alam, Md, Saiful Islam, A.B.M., Chyuan Ong, Hwai, Ashrafur Rahman, S.M., Najafi, G., Ahmed, S.F., Alhaz Uddin, Md., Mahlia, T.M.I. (2021). Impact of COVID-19 on the social, economic, environmental and energy domains: Lessons learnt from a global pandemic. Sustainable Production and Consumption, 26. https://doi.org/10.1016/j.spc.2020.10.016.

Morozov, V., Mezentseva, O., \& Proskurin, M. (2020). Trainable neural networks modelling for a forecasting of start-up product development. IEEE Third International Conference on Data Stream Mining \& Processing, 55-60. 
Moyo, N. (2020). Antecedents of employee disengagement amid COVID-19 pandemic. Polish Journal of Management Studies, 22(1), 323-334. DOI: $10.17512 /$ pjms.2020.22.1.21.

Nagy, Z.B., Kiss, L.B. (2018). The examination of appearance of income inequality in scientific databases with content analysis. Business Ethics and Leadership, 2(4), 35-45. http://doi.org/10.21272/bel.2(4).35-45.2018.

Okuneviciute Neverauskiene, L., \& Rakauskiene, O.G. (2018). Identification of employment increasing possibilities in the context of the EU socio-economic environment evaluation: The case of Lithuania. Economics and Sociology, 11(4), 51- 68. doi:10.14254/2071-789X.2018/11-4/3.

Petrushenko, Y., Vadym, A., Vorontsova, A., \& Ponomarenko, O. (2020). Sustainable development goals as a tool for strategic planning in communities: A bibliometric analysis of research. Paper presented at the E3S Web of Conferences, 202. doi:10.1051/e3sconf/202020203005.

Petrushenko, Y., Kostyuchenko, N., Smolennikov, D., \& Vorontsova, A. (2017). Impact of the participatory financing of international development projects on social capital of the local communities. Problems and Perspectives in Management, 15(3), 183-192. doi:10.21511/ppm.15(3-1).2017.02.

Przytuła, S., Strzelec, G., \& Krysińska-Kościańska, K.(2020). Re-vision of future trends in human resource management (HRM) after COVID-19. Journal of Intercultural Management, 12(4), 70-90. DOI 10.2478/joim-2020-0052.

Raychev, S., Dimitrova, G., Madzhurova, B., \& Stoyanova, D. (2020). Innovations as a factor for economic growth and labor market development. Marketing and Management of Innovations, 3, 22-31. http://doi.org/10.21272/mmi.2020.3-02.

Rosokhata, A., Rybina O., Derykolenko, A., \& Makerska, V. (2020). Improving the classification of digital marketing tools for the industrial goods promotion in the globalization context. Research in World Economy, 11 (4), Special Issue, 42-52. doi:10.5430/rwe.v11n4p42.

Rui, L., Sineviciene, L., Melnyk, L., Kubatko, O., Karintseva, O., \& Lyulyov, O. (2019). Economic and environmental convergence of transformation economy: The case of China. Problems and Perspectives in Management, 17(3), 233-241. doi:10.21511/ppm.17(3).2019.19.

Sawangchai, A., Prasarnkarn, H., Kasuma J., Polyakova A.G., \& Qasim, S. (2020). Effects of COVID-19 on digital learning of entrepreneurs. Polish Journal of Management Studies, 22(2), 502-517. DOI: 10.17512/pjms.2020.22.2.33.

Semenenko, I., Halhash, R., \& Sieriebriak, K. (2019). Sustainable development of regions in Ukraine: before and after the beginning of the conflict. Equilibrium. Quarterly Journal of Economics and Economic Policy, 14(2), 317-339. https://doi.org/10.24136/eq.2019.015.

Smiianov, V. A., Vasilyeva, T. A., Chygryn, O. Y., Rubanov, P. M., \& Mayboroda, T. M. (2020a). Socio-economic patterns of labor market functioning in the public health: challenges connected with COVID-19. Wiadomosci Lekarskie, 73(10), 2181-2187.

Smiianov, V. A., Lyulyov, O. V., Pimonenko, T. V., Andrushchenko, T. A., Sova, S., \& Grechkovskaya, N. V. (2020b). The impact of the pandemic lockdown on air pollution, health and economic growth: system dynamics analysis. Wiadomosci Lekarskie, 73(11), 2332-2338.

Smiianov, V. A., Smiianova, O. I., Gruzieva, T. S., Vygivska, L., \& Rudenko, L. A. (2017). Study of motivational factors in doctors in respect of healthcare quality improvement. Wiadomosci Lekarskie, 70(1), 27-31.

State Statistics Service of Ukraine (2021). Retrieved from http://www.ukrstat.gov.ua/. 
Stukalo, N., Lytvyn, M., Petrushenko, Y., \& Omelchenko, Y. (2020). The achievement of the country's sustainable development in the conditions of global threats. Paper presented at the E3S Web of Conferences, 211. doi:10.1051/e3sconf/202021101029.

Sułkowski, Ł. (2020). COVID-19 pandemic; recession, virtual revolution leading to deglobalization? Journal of Intercultural Management, 12(1), 1-11. DOI 10.2478/joim2020-0029.

Sumiyana, S. (2020). Different characteristics of the aggregate of accounting earnings between developed and developing countries: Evidence for predicting future GDP. Journal of International Studies, 13(1), 58-80. doi:10.14254/2071- 8330.2020/13-1/4.

Teletov, A.S., Teletova, S., \& Letunovska, N. (2019). Use of language games in advertising texts as a creative approach in advertising management. Periodicals of Engineering and Natural Sciences, 7(2), 458-465. DOI: 10.21533/pen.v7i2.569.g314.

Vasilyeva, T., Bilan, S., Bagmet, K., \& Seliga, R. (2020). Institutional development gap in the social sector: Crosscountry analysis. Economics and Sociology, 13(1), 271-294. doi:10.14254/2071-789X.2020/13-1/17.

Vasilyeva, T., Kuzmenko, O., Bozhenko, V., \& Kolotilina, O. (2019). Assessment of the dynamics of bifurcation transformations in the economy. Paper presented at the CEUR $\begin{array}{lll}\text { Workshop } \quad \text { Proceedings, } & 2422 & 134-146 .\end{array}$ https://doi.org/10.1051/shsconf/20196504006.

Vo, D.H. (2020). Sustainable agriculture \& energy in the U.S.: a link between ethanol production and the acreage for corn. Economics and Sociology, 13(3), 259-268. doi:10.14254/2071-789X.2020/13-3/16.

Vrbka, J. (2020). The use of neural networks to determine value based drivers for SMEs operating in the rural areas of the Czech Republic. Oeconomia Copernicana, 11(2), 325-346. doi: 10.24136/oc.2020.014.

Vysochyna, A., Kryklii, O., Minchenko, M., Aliyeva, A. A., \& Demchuk, K. (2020). Country innovative development: impact of shadow economy. Marketing and Management of Innovations, 4, 41-49. http://doi.org/10.21272/mmi.2020.4-03.

Worldometers (2021). COVID-19 Coronavirus pandemic. Retrieved from: https://www.worldometers.info/coronavirus/?utm_campaign=homeAdvegas 1 ?\%22 (9.01.2021).

Yarovenko, H., Bilan, Y., Lyeonov, S., \& Mentel, G. (2021). Methodology for assessing the risk associated with information and knowledge loss management. Journal of Business Economics and Management, 22(2), 369-387. doi:10.3846/jbem.2021.13925.

Yelnikova, Y., Miskiewicz, R. (2020). Implementation mechanism of impact investing in the post-conflict regions. Financial Markets, Institutions and Risks, 4(3), 53-62. https://doi.org/10.21272/fmir.4(3).53-62.2020.

Yiu, L., Saner, R., \& Bardy, R. (2020). Collective action on public goods for sustainable development: ethics in action. Business Ethics and Leadership, 4(4), 14-27. https://doi.org/10.21272/bel.4(4).14-27.2020.

Zhang, H., Li, R., Cai, Z., Gu, Z., Heidari, A. A., Wang, M., ... \& Chen, M. (2020). Advanced orthogonal moth flame optimization with Broyden-Fletcher-Goldfarb-Shanno algorithm: Framework and real-world problems. Expert Systems with Applications, 159, 113617.

Zolkover, A., Renkas, J. (2020). Assessing the level of macroeconomic stability of EU $\begin{array}{llll}\text { Countries. SocioEconomic } & \text { Challenges, } & \text { 4(4), } & \text { 175-182. }\end{array}$ https://doi.org/10.21272/sec.4(4).175-182.2020. 